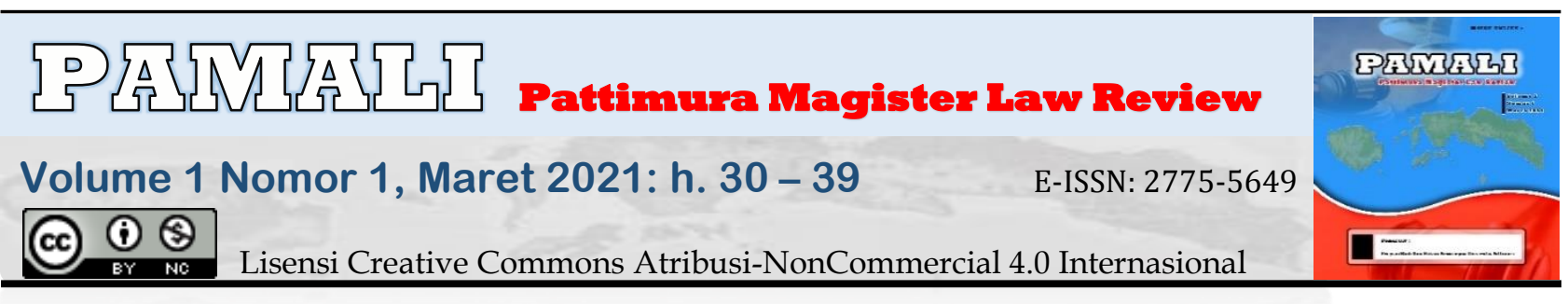

\title{
Sasi Sebagai Kearifan Lokal dalam Mencegah Menularnya Covid-19 Di Provinsi Maluku
}

\section{La Ode Angga}

Fakultas Hukum Universitas Pattimura, Ambon, Indonesia.

@: laodeangga@yahoo.com

: $x x x x x x x x x x x x x x x x$

Dikirim: 07/01/2021

\begin{tabular}{l}
\hline Info Artikel \\
Keywords: \\
Sasi Law; Local Wisdom; \\
Prevent Covid 19.
\end{tabular}

Kata Kunci:

Hukum Sasi; Kearifan Lokal; Mencegah Covid 19.

\begin{tabular}{l} 
Direvisi: 19/02/2021 Dipublikasi: 24/02/2021 \\
\hline Abstract \\
Introduction: Sasi means the prohibition of taking natural resources on land or \\
at sea, which is based on several important and basic arguments. The principle \\
on which the Sasi law is based is actually the principle of sustainable natural \\
resource management.
\end{tabular} Purposes of the Research: Know and analyze the role of sasi law as local wisdom in preventing the spread of Covid 19 in the Maluku Province. the formulation of Sasi's law in expanding its meaning and scope of implementation, so that the place is applied in preventing the spread of Covid 19 in Maluku Province.

Methods of the Research: This research was conducted using a juridical empirical approach which is a descriptive study of qualitative analysis. The research seeks to describe the Role of Sasi Law as Local Wisdom in Preventing the Transmission of Covid 19 in Maluku Provision.

Results of the Research: The Sasi Law which is owned by the Indigenous Maluku people, especially Southeast Maluku, of course the Sasi Law (Adat Hawear) in Southeast Maluku Regency can be applied in the prevention of Covid 19 in Southeast Maluku Regency by holding customary deliberations (which is followed by Adat leaders (adat leaders) The customary leaders (traditional leaders) held deliberations and formulated customary law norms as to what would be applied to preventing pollution from spreading Covid 19.

\footnotetext{
Abstrak

Latar Belakang: Sasi mengandung makna larangan untuk mengambil sumberdaya alam di darat maupun di laut, yang didasarkan pada beberapa argumentasi penting dan mendasar.Prinsip yang menjadi tumpuan bagi adanya hukum Sasi sebenarnya adalah prinsip tata kelola sumberdaya alam secara berkelanjutan.

Tujuan Penelitian: Mengetahui dan menganalisis peran hukum sasi sebagai kearifan lokal dalam melakukan pencegahan menularnya Covid 19 di Provisi Maluku. formulasi hukum Sasi dalam memperluas makna dan jangkauan keberlakuannya, sehingga tempat diterapkan dalam melakukan pencegahan menularnya Covid 19 di Provisi Maluku

Metode Penelitian: Penelitian ini dilakukan dengan menggunakan pendekatan yuridis emperis yang bersifat kajian deskriptif analisis kualitatif. Penelitian berusaha menggambarkan Peran Hukum Sasi Sebagai Kearifan Lokal Dalam Mencegah Menularnya Covid 19 di Provisi Maluku.

Hasil Penelitian: Hukum Sasi yang dimiliki oleh masyarakat Adat Maluku Khususnya Maluku Tenggara, tentu saja Hukum Sasi (Adat Hawear) di Kabupaen Maluku Tenggara dapat diterapkan dalam
} 
pencegahan Covid 19 di Kabupaten Maluku Tenggara dengan cara melakukan musyawarah adat (yang diikuti oleh pimpinann Adat (petua-petua adat). Pimpinan Adat (Petua-petua adat) tersebut mengadakan musyawarah dan merumuskan norma hukum adat yang seperti apa yang akan diberlakukan pada pencegahan pencemaran menyebaran Covid 19.

\section{Pendahuluan}

Eksistensi masyarakat hukum adat telah diakui oleh Negara ${ }^{1}$, salah satu hukum adat di Maluku yaitu Hukum Sasi. Hukum Sasi sejak lama sudah dikenal di Maluku dan mempunyai peran yang penting dalam menata kehidupan khususnya masyarakat hukum adat. Sasi mengandung makna larangan untuk mengambil sumberdaya alam di darat maupun di laut, yang didasarkan pada beberapa argumentasi penting dan mendasar. Prinsip yang menjadi tumpuan bagi adanya hukum Sasi sebenarnya adalah prinsip tata kelola sumberdaya alam secara berkelanjutan. Pemikiran arif yang berkembang secara lokal ini didasarkan juga pada aspek ekonomi masyarakat negeri dan desa serta kampong, yang berada pada pulau-pulau kecil.

Masyarakat adat yang hidup pada pulau-pulau kecil, jumlahnya cukup banyak dan jika dibandingkan dengan sumberdaya alam yang tersedia. Jadi dapat dikatakan bahwa hal itu tidak cukup untuk memenuhi kebutuhan dasar masyarakat adat, untuk jangka waktu tertentu. Oleh karena itu lahirlah pemikiran untuk membuat atura hukum yang dapat mengatur dan menata seluruh potensi sumberdaya alam tersebut agar bisa dimanfaatkan secara bijaksana.

Sumberdaya alam di darat yang dimaksud misalnya, kelapa muda, nenas, durian, langsat, daun sagu, daun nayang atau enau, Sumberdaya alam di laut yang dimaksud misalnya ikan, bioata laut, terumbu karang, pasir pantai, batu batuan, dan sebagainya.Fakta yang terjadi di Kepulauan Kei Maluku Tenggara, Sasi itu tidak hanya terkait dengan sumberdaya alam, tetapi sudah diperluas termasuk aturan yang terkait dengan manusia dan benda-benda lainnya.

Bebarapa contoh yang dapat dikemukakan antara lain; Sasi diterapkan untuk melarang melewati jakan dan jembatan, sasi bangunan-bangunan tertentu yang dianggap bermasalah sehingga tidak boleh dimanfaatkan. Sasi juga diterapkan untuk melindungi anak perempuan, sehingga tidak dibawa lari oleh laki laki pacarnya (kawin lari) dan sebagainya. Jadi sebenarnya hukum Sasi mengandung makna yang mendalam dan luas, sehingga jika dihayati dan diterapkan secara baik, sebagai bagian dari instrument hukum adat, masyarakat Maluku, maka pasti ada manfaatnya bagi kehidupan masyarakat pada umumnya.

Corona Virus Disease-19 (COVID-19) berdampak signifikan terhadap seluruh aspek kehidupan manusia di dunia, terutama di Indonesia yang wilayahnya sangat luas dan berpenduduk besar (sekitar 267 juta jiwa) dengan berbagai jenis profesi ${ }^{2}$. Pandemi COVID-19 sangat berpengaruh besar di Indonesia, dimana Indonesia merupakan salah satu negara yang mempunyai populasi manusia yang sangat padat ${ }^{3}$. Oleh karena itu dalam menghadapi mewabahnya Virus Corona (Covid 19), maka hukum Sasi juga dapat digunakan sebagai salah satu instrumen untuk mencegah

\footnotetext{
1 Jenny Kristiana Matuankotta, “Pengakuan Dan Perlindungan Hukum Terhadap Eksistensi Pemerintahan Adat," SASI 26, no. 2 (2020): 188-200, https:/ / doi.org/10.47268/sasi.v26i2.305.

2 Kunarso and A Djoko Sumaryanto, “Eksistensi Perjanjian Ditengah Pandemi Covid-19," Batulis Civil Law Review 1, no. 1 (2020): 33-46, https://doi.org/10.47268/ballrev.v1i1.423.

3 Taun and Ananda Nugraha, "Penerapan Hukum Dalam Pemutusan Hubungan Kerja Dan Kebijakan Bank Terhadap Debitur Yang Terdampak Pandemi Covid-19," Batulis Civil Law Review 1, no. 1 (2020): 24-32, https://doi.org/10.47268/ballrev.v1i1.422.
} 
menularnya virus tersebut dari manusia ke manusia. Penerapan hukum Sasi, yang ditujukan kepada manusia, sebenarnya ada relevansinya untuk mencegah lalulintas orang pada wilayahwilayah tertentu sehingga tidak terjadi penularan yang massif dan terjadi dalam skala besar. Misalnya dengan membuat tanda Sasi pada wilayah-wilayah tertentu di suatu Negeri dan Desa, maka dengan sendirinya orang tidak akan melintasi di wilayah wilayah tersebut, sehingga dapat mencegah pergerakan manusia dari satu tempat ke tempat yang lain.

Walaupun hukum Sasi itu tidak tertulis namun mengandung sanksi tertentu. Sanksi- sanksi dalam hukum sasi memang tidak terlalu berat sebagaimana layaknya hukum positip atau hukum negara, namun minimal dapat memberikan efek jera dari sisi adat. Jadi masyarakat adat yang tahu dan paham serta patuh kepada adat istiadat dan hukum adat, pasti akan tunnduk dan patuh pada hukum adat yakni hukum Sasi.

Penelitian ini penting (urgen) dalam rangka untuk melakukan formulasi norma hukum sasi dalam menegakkan hukum Sasi, dalam hal ini Sasi diterapkan dalam pencegahan menularnya Covid 19, maka lembaga Kewang atau lembaga pemerintahan lainnya seperti Raja dan Saniri sangat penting dan menentukan. Penegakan hukum membutuhkan beberapa sandaran untuk digunakan agar bermakna atau bermanfaat. Lembaga Kewang atau Polisi Hutan, harus mempunyai kemampuan dan kekuasaan dalam menegakkan hukum Sasi. Kewang harus mengetahui dan memahami hakikat atau makna dari norma-norma dalam hukum Sasi tersebut.Artinya hukum Sasi harus diperluas makna dan jangkauan keberlakuannya, sehingga tidak hanya ditujukan kepada sumberdaya alam, tetapi hukum Sasi juga berlaku bagi pergerakan orang atau manusia, yang akan memasuki wilayah tertentu. Jadi tempat-empat itu dinyatakan sebagai tempat yang disasi, sehingga orang tidak boleh melewati tempat-tempat tersebut, dalam rangka mencegah penularan Covid 19.

\section{Metode Penelitian}

Penelitian ini merupakan penelitian sosiolegal (sociolegal research), yakni metode penelitian kombinasi antara metode penelitian Hukum doktrinal dan metode penelitian Hukum empiris.Penelitian ini dilakukan di Provinsi Maluku.Jenis data penelitian ini adalah data primer dan data sekunder yang diperoleh melalui studi kepustakaan dan wawancara.Juga menggunakan pendekatan yuridis emperis yang bersifat kajian deskriptif analisis kualitatif ${ }^{4}$. Penelitian berusaha menggambarkanPeran Hukum Sasi Sebagai Kearifan Lokal dalam Mencegah Menularnya Covid 19 di Provisi Maluku. Cara kerja dari metode yuridis empiris atau yuridis sosiologis dalam usulan penelitian ini yaitu dari hasil pengumpulan dan penemuan data serta informasi melalui studi kepustakaan terhadap asumsi atau anggapan dasar yang dipergunakan dalam menjawab permasalahan pada penelitian ini, kemudian dilakukan pengujian secara induktif-verifikatif pada fakta mutakhir yang terdapat di dalam masyarakat, dengan demikian kebenaran dalam suatu penelitian telah dinyatakan reliable tanpa harus melalui proses rasionalisasi.

\section{Hasil dan Pembahasan}

\subsection{Peran Hukum Sasi Sebagai Kearifan Lokal Dalam Melakukan Pencegahan Menularnya Covid 19 Di Provisi Maluku}

Kearifan lokal merupakan warisan nenek moyang bangsa Indonesia dalam tata nilai yang menyatu dalam bentuk religi, budaya dan adat istiadat. Dalam perkembangan masyarakat melakukan adaptasi melalui lingkungannya dengan mengembangkan suatu kearifan yang berwujud pengetahuan atau ide dipadu dengan norma adat, nilai budaya dan aktifitas mengelola

4 Maria S. W. Sumardjono, Pendoman Pembuatan Usulan Penelitian Sebuah Panduan Dasar (Jakarta: Gramedia Pustaka Utama, 1996), h. 10. 
lingkungan guna mencukupi kebutuhan hidupnya. Jika kita melihat evolusi manusia dengan alam dimasa lampau telah terbentuk suatu hubungan yang harmonis dimana manusia berusaha hidup berdampingan secara damai dengan alam, dalam pandangan manusia alam itu besar dan bersifat sakral maka perlu hidup secara damai dengan alam sehingga tidak terjadi kerusakan alam yang akan menimbulkan kerugian pada manusia itu sendiri, dalam mendukung hubungan ini manusia menciptakan etika bertindak dan bertingkah laku terhadap alam, hampir sebagian besar suku di negara kita ini memeliki aturan-aturan yang dibuat yang disebut sebagai kearifan lokal ${ }^{5}$.

Kearifan lokal dan Lembaga Adat adalah sesuatu yang didambakan umat manusia di dunia ini.Kearifan dimulai dari gagasan-gagasan dari individu yang kemudian bertemu dengan gagasan individu lainnya, seterusnya berupa gagasan kolektif.Kearifan lokal ini biasanyadicipta dan dipraktikkan untuk kebaikan komunitas yang menggunakannya.Kearifan lokal ini juga tidak dapat dilepaskan dari kebudayaan masyarakat yang mendukungnya. Kearifan lokal, biasanya mencakup semua unsur kebudayaan manusia, yang mencakup: sistem religi, bahasa, ekonomi, teknologi, pendidikan, organisasi sosial, dan kesenian. Kearifan lokal bermula dari ide atau gagasan, yang kemudian diaplikasikan dalam tahapan praktik, dan penciptaan material kebudayaan. Melalui skripsi ini, penulis akan menguraikan beberapa contoh kearifan lokal dalam konteks pembentuka karakter bangsa Indonesia ${ }^{6}$.

Kearifan lokal yang dimaksud bisa saja berasal dari kebudayaan etnik, atau pemikiran kebangsaan dari masyarakat Indonesia, dari rentangan masa ke masa.Suku sahu yang mendiami lembaga yang bernama ji'o Japung Malamo (Daerah yang memiliki lembaga yang luas) di Kabupaten Halmahera Barat Provinsi Maluku Utara terdiri atas dua kelompok masyarakat adat yaitu Tala'I dan Padusua(Ji'o Tala'I re Padusua). Kedua kelompok masyarakat ini memiliki kesamaan dalam budaya dalam wujud benda-benda hasil karya manusia / arsitektur rakyat yang dinamakan sasadu (Rumah adat) namun terdapat perbedaan dalam dialektika tutur bahasa masing-masing kelompok yang terkenal dengan bahasa Sahu dialek Tala'I dan bahasa Sahu dialek padusua.

Dampak virus Corona yang dikenal juga dengan sebutan Covid-19 telah menjadi wabah berskala global. Hampir semua negara telah terpapar virus ini.Baik yang tinggal di perkotaan ataupun pedesaan.Tak terkecuali masyarakat adat di Nusantara yang jumlah ribuan komunitas. Masyarakat adat dengan berbagai kearifannya memiliki beragam cara menghadapi wabah ini. Salah satunya bisa ditemui di masyarakat adat Banua Lemo, yang berada di Desa Bonelemo, Kecamatan Bajo Barat, Kabupaten Luwu, Sulawesi Selatan.

Baso' Gandangsura, Kepala Desa Bonelemo, menyatakan bahwa menghadapi wabah Corona ini mereka telah melakukan berbagai upaya pencegahan berdasarkan kearifan lokal setempat. Salah satunya dengan melakukan karantina wilayah dengan cara menutup sementara akses masuk kampung dan membentuk Kampung Siaga Covid-19yang beranggotakan pemuda-pemudi dan ibuibu PKK Desa Bonelemo7.

Dengan adanya pandemic virus Covid 19komunitas adat di Indonesia didorong agar patuh pada segala imbauan pencegahan penyebarannya. Peran mereka penting untuk mencegah penyebaran Covid-19 tidak semakin meluas. Peneliti Ahli Utama bidang Kebudayaan Lembaga Ilmu

\footnotetext{
5 Christeward Alus, "Peran Lembaga Adat Dalam Pelestarian Kearifan Lokal Suku Sahu Di Desa Balisoan Kecamatan Sahu Kabupaten Halmahera Barat," Acta Diurna 3, no. 4 (2014): 1-16, https://ejournal.unsrat.ac.id/index.php/actadiurnakomunikasi/article/view/5995.

${ }^{6}$ Alus.

7 Wahyu Chandra, “Hadapi COVID-19, Masyarakat Adat Banua Lemo Karantina Wilayah Hingga Jaga Stok Pangan," mongabay.co.id, 2020, https://www.mongabay.co.id/2020/04/13/hadapi-covid-19-masyarakat-adat-banualemo-karantina-wilayah-hingga-jaga-stok-pangan/.
} 
Pengetahuan Indonesia (LIPI), Alie Humaedi, mengakui imbauan yang disampaikan pemerintah sedikit bertentangan dengan kultur masyarakat adat Indonesia pada umumnya.

Imbauan tersebut diantaranya social distancing atau menjaga jarak antara yang satu dengan yang lain serta menghindari kerumunan ${ }^{8}$.Dilema Pesta Adat Pernikahan Batak di Tengah Merebaknya Virus Corona Dia menilai, hampir dalam setiap keseharian kita selalu bersinggungan dengan orang lain, terutama dalam acara adat."Nah secara umum dalam siklus kehidupan dan ritual, upacara siklus kehidupan baik kelahiran, kematian, perkawinan hampir menuntut kolektivitas atau komunalitas.

Namun dalam keadaan ini, diperlukan kesedian setiap individu untuk mencari strategi untuk menjalankan budaya kolektifitas, namun tidak menganggu keinginan orang lain untuk tetap hidup sehat. Baca juga: Keluh Kesah Warga yang Tunda Pernikahan dan Ruginya Pengusaha Catering akibat Corona Alie menekankan upaya ini bukan berarti mengubah substansi budaya seutuhnya. "Caranya apa? Ya mungkin caranya tetap dengan kebiasaan upacara siklus kehidupan tetap dilakukan seperti pernikahan, kelahiran dan acara adat lain tetapi kemudian ada keadaban publiknya. Satu, menggunakan masker. Dua, menggunakan hand sanitizer. Tiga, mengambil jarak dulu.Jadi tetap acara itu berlangsung," terang dia. Kesehatan harus utama.

Dalam masyarakat Maluku diakui, masyarakat Evav tempo dulu masih hidup berkelompok dalam persekutuan kelompknya masing-masing dengan hukum lokalnya sendiri-sendiri, misalnya di desa Laar Itel (kini Elaar) ada hukum lokalnya Sasaktel, kemudian Desa Reli Badamas (kini Matwair) dengan hukum lokalnya Kot Fit atau Desa Dabraan, (Danar) dengan hukum lokalnya Yetomat Balwirin. "hukum lokal itu sangat dihormati, dipatuhi dan dijunjung tinggi oleh kelompok masyarakat setempat dalam kehidupan sehari-hari, namun seiring perjalanan waktu, maka pada abad 14 bertetapatan dengan permufakatan hukum Larvul Ngabal untuk diberlakukan di seluruh Kepulauan Kei, maka Hawear Balwirin diterima masyarakat adat Ur Siw Lor Lim, karena Hawear Balwirin merupakan bagian tak terpisahkan dari Hukum adat Larvul Ngabal“ 9 .

Nama Balwirin berasal dari Wirin Bal Romlob yang adalah nama Wirin di desa Dabraan (kini Danar). "wirin adalah daerah pesisir yang ditumbuhi banyak pohon kelapa dimana, lapis permukaan tanahnya berwarna hitam keabu-abuan yang tebalnya kurang lebih $20 \mathrm{~cm}$, selebihnya adalah pasir putih“. Daun kelapa muda (janur kuning), yang pertama kali diambil untuk membuat sasi (hawear), diambil dari pohon kelapa yang tumbuh di wirin Bal Rumlob, maka pada saat itulah Hawear itu diberi nama Hawear Balwirin, bukan Hawear Balwarin sebagaimana yang sering disebut- sebut orang selama ini.

Gerson Rahanubun menjelaskan, Hawear Balwirin, memiliki dua fungsi yaitu fungsi pidana, apabilah dua orang yang bertikai dakam skala besar seperti kerusuhan tahun 1999 lalu di Kei, maka perdamaian tersebut dilakukan dalam satu upacara adat yang dihadiri Rat, Orang Kai, Soa, Saniri dan pihak yang bermasalah. "pemangku adat menyelesaikan perselisihan tersebut secara kekeluargaan, atas kesepakatan damai dan saling memaafkan antar kedua pihak. Perdamaian itu digelar dalam satu upacara ritual adat yang disebut Hawear Nam Sait, Ni Baran Nas Or artinya sasi ditarik terbelah dua, dan anak panah dilayangkan/ dipanah ke udara.

Sedangkan fungsi perdata, untuk melindungi harta benda pribadi atau umum misalnya kelapa, Lola, teripang dan lain-lain. "apabilah salah satu desa ingin kelapa disasi, maka terlebih

8 Walda Marison, “Komunitas Adat Didorong Patuh Imbauan Pencegahan Penyebaran Covid-19,” Kompas.com, 2020, https://megapolitan.kompas.com/read/2020/03/19/14374271/komunitas-adat-didorong-patuh-imbauanpencegahan-penyebaran-covid-19.
9 Wikipedia,
"Hukum Larvul
Ngabal,"
wikipedia.org,
2020,

https://id.wikipedia.org/wiki/Hukum_Larvul_Ngabal. 
dahulu diadakan musyawarah desa untuk menentukan waktu yang tepat untuk sasi da berapa lama sasi tersebut dipasang, sasi didirikan di tempat terbuka, agar semua orang dapat melihatnya, kurun waktu sasi didirikan sampai membukan sasi disebut Yetut ${ }^{10}$.

Peradaban suatu bangsa sangat dipengaruhi dan ditentukan oleh kebudayaan setempat, demikian pula bagi masyarakat di Kepulauan Kei (Nuhu Evav), diktum leluhur tempo dulu diatas pentas kehidupan sehari-hari nyata dan alamia yaitu Hira Ni Natub Fo Ini, It Did Natub Fo It Did yang berarti miliki seseorang tetap miliknya, dan milik kita tetap milik kita. "secara batinia mengandung pengakuan dan penghargaan, kesadaran, keluhuran, larangan, perbatasan, hak asasi dan hukum untuk jangan mencuri, merampok, merampas, memanipulasi, melecehkan serta menipu harta milik orang lain".

Empat petuah terawal merupakan ringkasan hukum pidana yang disebut Hukum Nevnev, dan diyakini sebagai Hukum Laroul yang dirumuskan dalam pertemuan para mel pembentuk serikat sembilan di Elaar, Nuhu Roa. Dua petuah berikutnya adalah ringkasan hukum keluarga yang disebut Hukum Hanilit, sementara petuah terakhir adalah ringkasan hukum properti yang disebut Hukum Hawear Balwirin. Hukum Hanilit dan Hukum Hawear Balwirin diyakini merupakan Hukum Ngabal yang dirumuskan dalam pertemuan para mel pembentuk serikat lima di Ler Ohoilim, Yūt.

Dilihat dari kekuatan mengikat Hukum Sasi (Adat Hawear) maka peneliti mengharapan Adat Hawear ini diterapan dalam pencegahan menularnya Covid 19 di Kabupaten Maluku Tenggara, supaya masyarakat Maluku Tenggara tidak tertulari atau tidak menularkan pada manusia lain. Menurut peneliti Adat Hawear yang berlaku pada masyarakat Adat Hawear di Kabupaen Maluku Tenggara, baik kei besar maupun Kei Kecil, ini merupakan suatu prinsip kehati-hatian (pencegahan dini) dalam pengelolaan sumber alam mereka supaya bisa dinikmati hasilnya oleh generasi mereka dan gererasi masa yang akan datang. Dimana prinsip kehati-hatian (pencegahan dini) dan prinsip keberlanjutan adalah merupakan prinsip hukum ingkungan yang utama dalam perlindungan dan pengelolaan lingkungan hidup baik pada skala regional, nasional maupun internasional.Prinsip Adat Hawear di atas tentu saja merupakan Hukum Sasi yang dimiliki oleh masyarakat Adat Maluku Khususnya Maluku Tenggara, tentu saja relevan untuk bisa diterapkan pada pencegahan Covid 19.

\subsection{Formulasi Norma Hukum Sasi Dalam Memperluas Makna Dan Jangkauan Keberlakuannya, Sehingga Tempat Diterapkan Dalam Melakukan Pencegahan Menularnya Covid 19 Di Provisi Maluku}

Hukum Sasi (Adat Hawear) di Kabupaen Maluku Tenggara menurut peneliti bisa diterapkan dalam pencegahan Covid 19 di Kabupaten Maluku Tenggara dengan cara melakukan musyawarah adat (yang diikuti oleh pimpinann Adat (petua-petua adat). Pimpinan Adat (Petua-petua adat) tersebut mengadakan musyawarah dan merumuskan norma hukum adat yang seperti apa yang akan diberlakukan pada pencegahan pencemaran menyebaran Covid 19. Sehingga masalah yang dihadapi oleh masyarakat Adat Haweardi bidang Covid 19 pada wilayah pesisir, laut dan pulaupulau kecil Kabupaten Maluku Tenggara.

Untuk memperkuat asumsi peneliti bahwa hawear dapat diterapkan untuk pencegahan Covid 19 pada pesisir laut di Kabupaten Maluku Tenggara, maka peneliti melakukan wawancara dengan toko Adat (Petua Adat) Maluku Tenggara Bapak Lau Rahantoknam, mengatakan:

"Hawear tanda larangan untuk melindungi milik orang seperti sasi juga bisa dipakai sebagai tanda larangan yang digunakan orang lain secara paksa, hawear juga untuk melindungi kelestsrian lingkungan hidup. Seperti sasi meti, sasi dusun tanaman untuk jangka waktu

10 Neri Rahabav, “Makna Hawear Balwirin Yang Terkoyak,” Koran Vox Populi, 2011, http://tenggararaya.blogspot.com/2011/04/makna-hawear-balwirin-yang-terkoyak.html. 
tertentu tujuanya untuk memperoleh hasil yang banyak. Tempat yang disasi tersebut diberi nama Yot nama dusun yang disasi diberi tandah hawear, hewear itu untuk melindungi barang kita dari gangguan orang. Sedankan dalam perlindungan dan pengelolaan lingkungan hidup pesisir laut dapat diterapkan Hawear (sasi) untuk melakukan pencegahan pencemaran dan perusakan lingkungan hidup pada pesisir laut di Kabupaten Maluku Tenggara".

Senada dengan toko Adat (Petua Adat), Fansisks Kwas Setitit pada saat saya melakukan wawancara dengan toko pemuda (Mahasiswa Fakultas Hukum) dari Kabupaten Maluku Tenggara menyatakan:

“Bahwa Adat Hawear dapat dilakukan pada rana publik, rana publik termaksud di dalamnya Hawear (sasi) untuk perlindungan dan pengelolaan lingkungan hidup, terkhusus untuk melakukan pencegahan pencemaran dan perusakan lingkungan hidup pada pesisir laut di Kabupaten Maluku Tenggara".

Dari hasil wawancara kedua toko di atas, pada prinsipnya Hukum Sasi (Adat Hawear) dapat diterapkan dalam pencegahan menularnya Covid 19, di Maluku terkhusus di Maluku Tenggara, untuk menjaga keberlakukan efektivitas dari rumusan norma hukum tersebut di atas dapat digunakan teori efektivitas hukum yang dikemukakan oleh Soerjono Soekanto. Teori efektivitas hukum menurut Soerjono Soekanto, adalah bahwa efektif atau tidaknya suatu hukum ditentukan oleh 5 (lima) faktor, yaitu: 11

a) Faktor hukumnya sendiri (undang-undang).

b) Faktor penegak hukum, yakni pihak-pihak yang membentuk maupun menerapkan hukum.

c) Faktor sarana atau fasilitas yang mendukung penegakan hukum.

d) Faktor masyarakat, yakni lingkungan

e) dimana hukum tersebut berlaku atau diterapkan.

f) Faktor kebudayaan, yakni sebagai hasil karya, cipta dan rasa yang didasarkan pada karsa manusia di dalam pergaulan hidup.

Kelima faktor tersebut saling berkaitan satu sama lainnya, oleh karena merupakan esensi penegakan hukum, serta juga merupakan tolok ukur daripada efektivitas penegakan hukum ${ }^{12}$ Efektivitas dapat diartikan sebagai suatu proses pencapaian suatu tujuan yang telah ditetapkan sebelumnya. Suatu usaha atau kegiatan dapat dikatakan efektif apabila usaha atau kegiatan tersebut telah mencapai tujuannya. Apabila tujuan yang dimaksud adalah tujuan suatu instansi maka proses pencapaian tujuan tersebut merupakan keberhasilan dalam melaksanakan program atau kegiatan menurut wewenang, tugas dan fungsi instansi tersebut. Adapun apabila kita melihat efektivitas dalam bidang hukum, (Ali, 2010), berpendapat bahwa ketika kita ingin mengetahui sejauh mana efektivitas dari hukum, maka kita pertama-tama harus dapat mengukur "sejauh mana aturan hukum itu ditaati atau tidak ditaati". Lebih lanjut (Ali: 2010) mengemukakan bahwa:

"Pada umumnya faktor yang banyak mempengaruhi efektivitas suatu perundang-undangan adalah profesional dan optimal pelaksanaan peran, wewenang dan fungsi dari para penegak hukum, baik di dalam menjelaskan tugas yang dibebankan terhadap diri mereka maupun dalam menegakkan perundang-undangan tersebut".

11 Soeryono Soekanto, Faktor-Faktor Yang Mempengaruhi Penegakan Hukum (Jakarta: Raja Grafindo Persada, 2008), h. 8.

12 Masykuri, "Efektivitas, Hukum Penerapan Undang-Undang Nomor 41 Tahun 1999 Tentang Kehutanan Terhadap Penebangan Liar (Illegal Logging) Di Kabupaten Kolaka Utara Propinsi Sulawesi Tenggara" (Skripsi: Universitas Hasanuddin, 2013), h. 34. http://digilib.unhas.ac.id/opac/detail-opac?id=8302. 
Pada elemen pertama, yang menentukan dapat berfungsinya hukum tertulis tersebut dengan baik atau tidak adalah tergantung dari aturan hukum itu sendiri. Menurut Soerjono Soekanto, ukuran efektivitas pada elemen pertama adalah: ${ }^{13}$

a) Peraturan yang ada mengenai bidang-bidang kehidupan tertentu sudah cukup sistematis.

b) Peraturan yang ada mengenai bidang-bidang kehidupan tertentu sudah cukup sinkron, secara hierarki dan horizontal tidak ada pertentangan.

c) Secara kualitatif dan kuantitatif peraturan-peraturan yang mengatur bidang-bidang kehidupan tertentu sudah mencukupi.

Selnjutnya menurut peneliti untuk mendukung teori efektivitas hukum yang dikemukakan oleh Soerjono Soekanto harus ditunjang oleh teori kaida hukum. Teori Kaidah tersebut dibagi tiga macam hal yang mana dirumuskan sebagai berikut: 14

a) Kaidah hukum berlaku secara yuridis, apabila penentuannya didasarkan pada kaidah yang lebih tinggi tingkatannya atau terbentuk atas dasar yang telah ditetapkan.

b) Kaidah hukum berlaku secara sosiologis, apabila kaidah tersebut efektif. Artinya, kaidah dimaksud dapat dipaksakan berlakunya oleh penguasa walaupun tidak diterima oleh warga masyarakat (teori kekuasaan) atau kaidah itu berlaku karena adanya pengakuan dari masyarakat.

c) Kaidah hukum berlaku secara filosofis, yaitu sesuai dengan cita hukum sebagai nilai positif yang tertinggi.

Kalau dikaji secara mendalam, agar efektivitas hukum dalam masyarakat itu benar-benar berfungsi maka setiap kaidah hukum harus memenuhi ketiga macam unsur di atas, sebabagai berikut: 15

a) bila kaidah hukum hanya berlaku secara yuridis, ada kemungkinan kaidah itu merupakan kaidah mati;

b) kalau hanya berlaku secara sosiologis dalam arti teori kekuasaan, maka kaidah itu menjadi aturan pemaksa;

c) apabila hanya berlaku secara filosofis, kemungkinannya kaidah itu hanya merupakan hukum yang dicita-citakan (ius constituendum).

Berdasarkan penjelasan di atas, tampak betapa rumitnya persoalan efektivitas hukum dalam masyarakat di Indonesia khususnya masyarakat Adat Hawear di Kabupaen Maluku Tenggara.Oleh karena itu, agar suatu kaidah hukum atau peraturan tertulis benar-benar berfungsi, senantiasa dapat dikembalikan pada tiga kaida yang telah disebutkan di atas.

\section{Kesimpulan}

Dilihat dari kekuatan mengikat Hukum Sasi (Adat Hawear) maka peneliti mengharapan Adat Hawear ini diterapan dalam pencegahan menularnya Covid 19 di Kabupaten Maluku Tenggara, supaya masyarakat Maluku Tenggara tidak tertulari atau tidak menularkan pada manusia lain. Menurut peneliti Adat Hawear yang berlaku pada masyarakat Adat Hawear di Kabupaen Maluku Tenggara, baik kei besar maupun Kei Kecil, ini merupakan suatu prinsip kehati-hatian (pencegahan dini) dalam pengelolaan sumber alam mereka supaya bisa dinikmati hasilnya oleh generasi mereka

13 Soekanto, Faktor-Faktor Yang Mempengaruhi Penegakan Hukum.

14 Ria Ayu Novita, Agung Basuki Prasetyo, and Suparno, "Efektifitas Pelaksanaan Undang-Undang Nomor 2 Tahun 1960 Tentang Perjanjian Bagi Hasil Pertanian (Tanah Kering) Di Desa Beringin, Kecamatan Bayan, Kabupaten

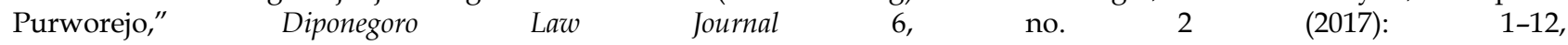
https:/ / ejournal3.undip.ac.id/index.php/dlr/article/view/16975.

15 Zainuddin Ali, Sosiologi Hukum (Jakarta: Sinar Grafika, 2006), h. 62-63. 
dan gererasi masa yang akan datang. Dimana prinsip kehati-hatian (pencegahan dini) dan prinsip keberlanjutan adalah merupakan prinsip hukum ingkungan yang utama dalam perlindungan dan pengelolaan lingkungan hidup baik pada skala regional, nasional maupun internasional. Prinsip Adat Hawear di atas tentu saja merupakan Hukum Sasi yang dimiliki oleh masyarakat Adat Maluku Khususnya Maluku Tenggara, tentu saja

Hukum Sasi (Adat Hawear) di Kabupaen Maluku Tenggara menurut peneliti bisa diterapkan dalam pencegahan Covid 19 di Kabupaten Maluku Tenggara dengan cara melakukan musyawarah adat (yang diikuti oleh pimpinann Adat (petua-petua adat). Pimpinan Adat (Petua-petua adat) tersebut mengadakan musyawarah dan merumuskan norma hukum adat yang seperti apa yang akan diberlakukan pada pencegahan pencemaran menyebaran Covid 19. Sehingga masalah yang dihadapi oleh masyarakat Adat Hawear di bidang Covid 19 pada wilayah pesisir, laut dan pulaupulau kecil Kabupaten Maluku Tenggara

\section{Referensi}

Ali, Zainuddin. Sosiologi Hukum. Jakarta: Sinar Grafika, 2006.

Alus, Christeward. "Peran Lembaga Adat Dalam Pelestarian Kearifan Lokal Suku Sahu Di Desa Balisoan Kecamatan Sahu Kabupaten Halmahera Barat." Acta Diurna 3, no. 4 (2014): 1-16. https://ejournal.unsrat.ac.id/index.php/actadiurnakomunikasi/article/view/5995.

Chandra, Wahyu. "Hadapi COVID-19, Masyarakat Adat Banua Lemo Karantina Wilayah Hingga Jaga Stok Pangan." mongabay.co.id, 2020. https://www.mongabay.co.id/2020/04/13/hadapi-covid-19-masyarakat-adat-banua-lemokarantina-wilayah-hingga-jaga-stok-pangan/.

Kunarso, and A Djoko Sumaryanto. "Eksistensi Perjanjian Ditengah Pandemi Covid-19." Batulis Civil Law Review 1, no. 1 (2020): 33-46. https:/ / doi.org/10.47268/ ballrev.v1i1.423.

Marison, Walda. “Komunitas Adat Didorong Patuh Imbauan Pencegahan Penyebaran Covid-19." Kompas.com,

https:/ / megapolitan.kompas.com/read/2020/03/19/14374271/komunitas-adat-didorongpatuh-imbauan-pencegahan-penyebaran-covid-19.

Masykuri. "Efektivitas, Hukum Penerapan Undang-Undang Nomor 41 Tahun 1999 Tentang Kehutanan Terhadap Penebangan Liar (Illegal Logging) Di Kabupaten Kolaka Utara Propinsi Sulawesi Tenggara." Universitas Hasanuddin, 2013. http://digilib.unhas.ac.id/opac/detailopac?id=8302.

Matuankotta, Jenny Kristiana. "Pengakuan Dan Perlindungan Hukum Terhadap Eksistensi Pemerintahan Adat." SASI 26, no. 2 (2020): 188-200. https:/ / doi.org/10.47268/sasi.v26i2.305.

Novita, Ria Ayu, Agung Basuki Prasetyo, and Suparno. “Efektifitas Pelaksanaan Undang-Undang Nomor 2 Tahun 1960 Tentang Perjanjian Bagi Hasil Pertanian (Tanah Kering) Di Desa Beringin, Kecamatan Bayan, Kabupaten Purworejo." Diponegoro Law Journal 6, no. 2 (2017): 1-12. https:/ / ejournal3.undip.ac.id/index.php/dlr/article/view/16975.

Rahabav, Neri. "Makna Hawear Balwirin Yang Terkoyak." Koran Vox Populi, 2011. http:// tenggararaya.blogspot.com/2011/04/ makna-hawear-balwirin-yang-terkoyak.html.

Soekanto, Soeryono. Faktor-Faktor Yang Mempengaruhi Penegakan Hukum. Jakarta: Raja Grafindo Persada, 2008.

Sumardjono, Maria S. W. Pendoman Pembuatan Usulan Penelitian Sebuah Panduan Dasar. Jakarta: 
Gramedia Pustaka Utama, 1996.

Taun, and Ananda Nugraha. "Penerapan Hukum Dalam Pemutusan Hubungan Kerja Dan Kebijakan Bank Terhadap Debitur Yang Terdampak Pandemi Covid-19." Batulis Civil Law Review 1, no. 1 (2020): 24-32. https:// doi.org/10.47268/ballrev.v1i1.422.

Wikipedia. "Hukum Larvul Ngabal." 2020. https://id.wikipedia.org/wiki/Hukum_Larvul_Ngabal. 